This item was submitted to Loughborough's Research Repository by the author.

Items in Figshare are protected by copyright, with all rights reserved, unless otherwise indicated.

\title{
Mapping digital technologies to pedagogies inspired by Bloom's taxonomy
}

PLEASE CITE THE PUBLISHED VERSION

https://library.iated.org/view/DUBE2020MAP

PUBLISHER

IATED

VERSION

AM (Accepted Manuscript)

PUBLISHER STATEMENT

This paper was accepted for publication in the EDULEARN20 Proceedings. 12th International Conference on Education and New Learning Technologies July 6th-7th, 2020 and the definitive published version is available at https://library.iated.org/view/DUBE2020MAP

\section{LICENCE}

CC BY-NC-ND 4.0

\section{REPOSITORY RECORD}

Dube, Tendai, and S.R. Williams. 2020. "Mapping Digital Technologies to Pedagogies Inspired by Bloom's Taxonomy". Loughborough University. https://hdl.handle.net/2134/14222327.v1. 


\title{
MAPPING DIGITAL TECHNOLOGIES TO PEDAGOGIES INSPIRED BY BLOOM'S TAXONOMY
}

\author{
T. Dube, S.R. Williams \\ Loughborough University (UNITED KINGDOM)
}

\begin{abstract}
With continuous developments in digital educational technology, it may be tempting for educators to use some of those technologies in their practices for the sake of it, like as a tick box exercise, without much thought about how best such technologies can fit with the different pedagogies. This can especially be the case when professional development reviews identify one of the areas needing development as the lack of usage of technology in teaching practice. The role of digital educational technology is to enhance or support the learning and teaching processes. Technology is not meant to replace the educators, but to extend their capabilities in facilitating learning. As such, pedagogy should remain at the centre of every learning activity with the aim to achieve learning outcomes in each of such activities. This paper is on mapping the various digital technologies to different learning pedagogies in order to help inform educators on the choice of digital technologies to employ in their learning activities, in a way that addresses their pedagogical approaches. The mapping hinges on the revised version (2001) of Bloom's taxonomy [1] to ensure that all levels of learning are represented.
\end{abstract}

Keywords: Pedagogy, educational technology, e-learning, teacher training, staff development

\section{INTRODUCTION}

When technology is carefully selected, it can make a huge difference to the students' learning experience. One of the mistakes educators make is planning their curriculum and/or lessons without considering what technology can aid the delivery of the learning activities, and later randomly try to fit one in. Inclusion of digital technology in learning and teaching activities should not be an after-thought, but it should be considered right from the curriculum development and/or module planning stages to ensure that it is appropriately embedded. This particularly helps with the selection of technology which fits with the pedagogy that is being planned to be adopted. Consequently, this promotes higher chances of successful implementation of the chosen technology, and achievement of the learning outcomes. As already indicated earlier, any technological enhancements to the learning activities should pivot around pedagogy. From its Greek roots, pedagogy basically refers to the art of teaching, that is, the methods employed to facilitate learning. It incorporates the theory and practice of teaching.

Bloom's taxonomy shapes the presentation of this paper. It is a framework that helps categorize learning objectives into six distinct categories in the cognitive domain. They are layered in a hierarchical manner, with concrete and fundamental levels forming the base, while abstract and complex levels build up to the top. The categories are: Remembering, Understanding, Applying, Analyzing, Evaluating, and Creating, in that order. These are clearly illustrated in Fig 1. Bloom's taxonomy has it that knowledge is built up from what has been previously learnt, hence starting from simply remembering facts and using those towards the ability to create something based on that information. As learning outcomes need to be measurable, verbs can be derived from each of the categories to enable evaluation of whether the learning outcomes were achieved or not. For example, "Remember" can't be used as is to determine having the basic knowledge but verbs like "recall" or "list" can be used to check if learners remember what they were taught.

The original Bloom's taxonomy was proposed in 1956 by Benjamin Bloom, an American educational psychologist. He subdivided the cognitive domain into six segments in the following order of increasing complexity: 1. Knowledge, 2. Understanding, 3. Application, 4. Analysis, 5. Synthesis, 6. Evaluation. The major revision was done by Bloom's original partner in the study, David Krathwohl, as well as Bloom's former student Lorin Anderson. One of the rationales of the change was to make learning outcomes measurable, hence the use of verbs instead of nouns. For example, the first subdivision 'Knowledge' which is a noun was changed to 'Remember', a verb. Also, the Evaluation subdivision that was originally at the top was demoted to $5^{\text {th }}$ position while Synthesis was renamed 'Create' and moved to the top. 


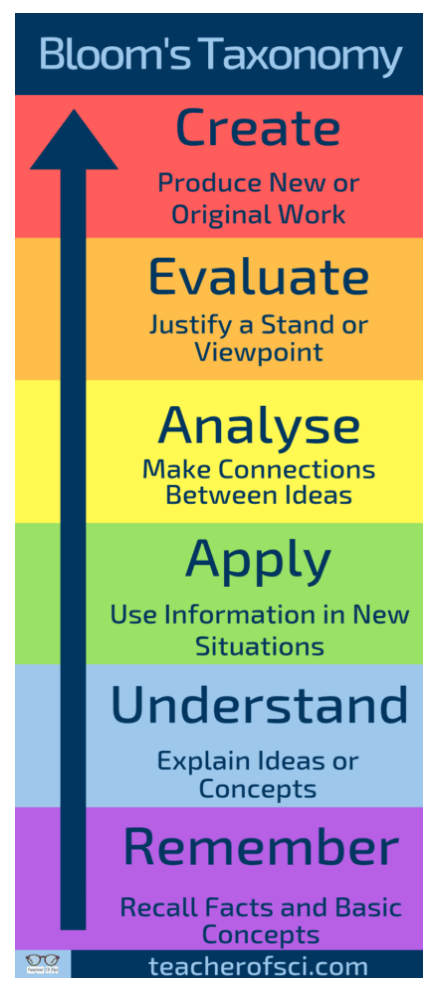

Figure 1. Bloom's Taxonomy [2].

\section{METHODOLOGY}

This paper is based on a desk research leading to the mapping of educational digital technologies to Bloom's taxonomy. Having identified the different learning categories according to the 2001 revised version of Bloom's taxonomy as shown in Fig 1, we then went on to identify the measurable verbs that can be used to formulate learning outcomes to determine if, or how much, learning had taken place at each of the levels. To achieve this, we used Microsoft Excel Spreadsheet. We copied and pasted Fig 1 onto an Excel sheet and entered the verbs into an adjacent column against each of the categories. Fig 2 gives a snapshot of this process while also revealing some of the selected verbs for each of the levels in Bloom's taxonomy.

\begin{tabular}{|c|c|c|}
\hline Bloom's Taxonomy & \multicolumn{2}{|l|}{ Verbs } \\
\hline Create & & \\
\hline Produce New or & \multirow{2}{*}{\multicolumn{2}{|c|}{ Assemble, arrange, code, combine, animate, construct, draw, compose, create, design, develop, formulate, }} \\
\hline Original Work & & \\
\hline \multirow{3}{*}{$\begin{array}{c}\text { Evaluate } \\
\text { Justify a Stand or } \\
\text { Viewpoint }\end{array}$} & & \\
\hline & \multicolumn{2}{|c|}{ Appraise, critique, determine, evaluate, explain, justify, rank, rate } \\
\hline & & \\
\hline \multirow{3}{*}{$\begin{array}{c}\text { Analyse } \\
\text { Make Connections } \\
\text { Between Ideas }\end{array}$} & & \\
\hline & \multicolumn{2}{|c|}{ Analyze, breakdown, dissect, separate, outline, order, investigate, examine, classify, compare, contrast } \\
\hline & & \\
\hline \multirow{3}{*}{$\begin{array}{c}\text { Apply } \\
\text { Use Information in New } \\
\text { Situations }\end{array}$} & & \\
\hline & \multicolumn{2}{|c|}{ Complete, calculate, compute, construct, demonstrate, determine, draw, examine, explore, modify, plot, } \\
\hline & & \\
\hline \multirow{3}{*}{$\begin{array}{l}\text { Understand } \\
\text { Explain Ideas or } \\
\text { Concepts }\end{array}$} & & \\
\hline & \multicolumn{2}{|c|}{ Describe, compare, contrast, classify, approximate, clarify, explain, distinguish, summarise } \\
\hline & & \\
\hline \multicolumn{3}{|l|}{ Remember } \\
\hline Recall Facts and Basic & \multirow[t]{2}{*}{ List, list, name, state, select, outline, match, label, identify } & \\
\hline $\begin{array}{l}\text { Recall Facts and Basic } \\
\text { Concepts }\end{array}$ & & \\
\hline
\end{tabular}

Figure 2. Deriving the verbs. 
Using the information collated as described above, we went on to identify different technologies that can be used for the learning and teaching activities in order to help fulfil the desired learning outcomes. Table 1 in the Results section therefore serves as a map to guide educators on what types of technologies can be used at the different levels of the Bloom's taxonomy given the learning outcomes set. It should be noted that these are only suggestions rather than prescriptions and more can be added to the lists. In addition to that, some of the suggested types of technologies can be used at other levels of the taxonomy as well. Successful use of these technologies depends on various things including careful planning as well as appropriate selection of the technologies.

\section{RESULTS}

In this section we present the major deliverable of our desk study. This is essentially the table showing the verbs derived from the six learning categories of the revised Bloom's taxonomy [3], as well as the suggested technologies inserted on the far right in Table 1. In the table, the categories are numbered from 1 up to 6 from the bottom up to represent the hierarchical structure of Bloom's taxonomy. Note that the type of technology that can be mapped or selected in actual practice will depend on the subject area. For example, any subject can have a learning outcome for students to develop (measurable verb) something to demonstrate their learning in category 6 of Bloom's taxonomy, thus ability to create (learning category) based on the acquired knowledge from the other lower level categories. However, not all subjects will need design or programming software to achieve that since development can be achieved using other technologies that have been listed, and/or others that have not been listed in Table 1.

\subsection{Technology-Pedagogy Mapping}

Table 1. Technologies mapped to Bloom's taxonomy and verbs.

\begin{tabular}{|c|c|c|}
\hline Categories & Verbs & Technologies \\
\hline 6. Create & $\begin{array}{l}\text { Assemble, arrange, code, combine, animate, } \\
\text { construct, draw, compose, create, design, } \\
\text { develop, formulate, generate, improve, integrate, } \\
\text { model, modify, plan, prepare, reproduce, } \\
\text { rearrange, reorganize, revise, rewrite, summarise }\end{array}$ & $\begin{array}{l}\text { Design software, Programming } \\
\text { software, animation packages, } \\
\text { blogs, wikis, video, podcasts, e- } \\
\text { portfolios }\end{array}$ \\
\hline 5. Evaluate & $\begin{array}{l}\text { Appraise, critique, determine, evaluate, explain, } \\
\text { justify, rank, rate }\end{array}$ & $\begin{array}{l}\text { Peer review software e.g. } \\
\text { WebPA (Loughborough's } \\
\text { homegrown application), text } \\
\text { editors e.g. Microsoft Word, } \\
\text { survey software }\end{array}$ \\
\hline 4. Analyze & $\begin{array}{c}\text { Analyze, breakdown, dissect, separate, outline, } \\
\text { order, investigate, examine, classify, compare, } \\
\text { contrast }\end{array}$ & $\begin{array}{l}\text { Data analysis software e.g. } \\
\text { Microsoft Excel spreadsheet, or } \\
\text { Tableau, etc, Presentation } \\
\text { software e.g. PowerPoint }\end{array}$ \\
\hline 3. Apply & $\begin{array}{l}\text { Complete, calculate, compute, construct, } \\
\text { demonstrate, determine, draw, examine, explore, } \\
\text { modify, plot, prepare, produce, solve, use, apply, } \\
\text { sketch }\end{array}$ & $\begin{array}{l}\text { Drawing and mathematical } \\
\text { software packages, simulation } \\
\text { software, laboratory software, } \\
\text { interactive whiteboards }\end{array}$ \\
\hline 2. Understand & $\begin{array}{c}\text { Describe, compare, contrast, classify, } \\
\text { approximate, clarify, explain, distinguish, } \\
\text { summarise }\end{array}$ & $\begin{array}{l}\text { Mind maps, e.g. Mind Gene, } \\
\text { Infographics }\end{array}$ \\
\hline 1. Remember & $\begin{array}{c}\text { List, list, name, state, select, outline, match, label, } \\
\text { identify }\end{array}$ & $\begin{array}{l}\text { Quiz tools e.g. Vevox, game- } \\
\text { based platforms }\end{array}$ \\
\hline
\end{tabular}




\section{CONCLUSIONS}

In this paper we have successfully demonstrated the possibility of mapping technologies to pedagogies guided by the revised version of Bloom's taxonomy. We believe that our effort in putting this together will guide especially new educators to choose technologies based on the pedagogies in question, and to help the learners achieve learning outcomes. If this guide is consulted right at the planning stages, careful thought would be put in the selection of the technologies leading to successful implementation. Pedagogy can thus remain the key focus of any learning and teaching activity while technology can be embedded in such activities to facilitate and promote variety of learning approaches. That in turn can also motivate the learners to stay engaged with their studies. Engaged students have higher chances of successfully completing their studies. As noted by other writers and researchers [4], we concur that indeed "theoretical understandings of learning can inform planned, purposeful activities to help students learn more effectively".

There is a lot of room for this map to be extended. For example, mapping can be done at subject level to help guide educators in specific subject areas. Our map can therefore form a base from which other similar developments can be made.

\section{REFERENCES}

[1] D. R. Krathwohl, A Revision of Bloom's Taxonomy: An Overview, Theory Into Practice, 41:4, 212-218, 2002, DOI: 10.1207/s15430421tip4104_2.

[2] P. Stevens-Fulbrook, "15 Learning Theories in Education (A Complete Summary)", 2019, Retrieved from https://teacherofsci.com/learning-theories-in-education/.

[3] J. Shabatura, "Bloom's Taxonomy Verb Chart", 2020, Retrieved from https://tips.uark.edu/blooms-taxonomy-verb-chart/.

[4] H. Beetham, H. (Ed.), Sharpe, R. (Ed.), "Rethinking Pedagogy for a Digital Age", New York: Routledge, 2020, https://doi.org/10.4324/9781351252805. 